\title{
Regulation of inflammation, antioxidant production, and methyl-carbon metabolism during methionine supplementation in lipopolysaccharide- challenged neonatal bovine hepatocytes
}

Qian Zhang and Heather M. White ${ }^{1}$

Department of Dairy Science, University of Wisconsin, Madison 53706
Supplementation of methionine (Met) may improve immunometabolic status, specifically during a period of inflammatory stress. The aim of the present study was to establish an inflammation model using primary neonatal bovine hepatocytes and to examine the effects of increasing concentrations of DL-Met and a maintained Met to lysine (Lys) ratio on hepatocyte inflammatory responses, antioxidant production, and Met metabolism during lipopolysaccharide (LPS) challenge. Hepatocytes isolated from 4 calves were maintained as monolayer cultures and exposed to 0,10 , or $40 \mu M$ DL-Met and 100 $\mu M$ Lys (0Met100Lys, 10Met100Lys, or 40Met100Lys) or $10 \mu \mathrm{M}$ DL-Met and $25 \mu \mathrm{M}$ Lys (10Met25Lys). Cells were exposed to each treatment for $16 \mathrm{~h}$ and then challenged with either 0 or $100 \mathrm{ng} / \mathrm{mL}$ of LPS for $8 \mathrm{~h}$. In the absence of LPS, glutathione (GSH) was not altered by 10 Met100Lys or 10 Met25Lys but was increased by 40Met100Lys. With LPS challenge, GSH concentration was decreased with 40Met100Lys and tended to be decreased with 10Met100Lys. Hepatocytes receiving 10Met100Lys treated with $100 \mathrm{ng} / \mathrm{mL}$ of LPS showed an inflammatory response with increased mRNA expression of tumor necrosis factor $(T N F \alpha), I L-6, I L-1 \beta$, and interferon gamma, which was accompanied by increased nuclear factor $\mathrm{\kappa B}$ inhibitor and serum amyloid A3 mRNA. The treatment 40Met100Lys was effective for preventing the LPS-induced increase in expression of the above genes except $T N F \alpha$. Similar preventative effects were observed for 10Met25Lys; however, it did not prevent the LPS-induced increase in $T N F \alpha$ or $I L-6$ mRNA. Lipopolysaccharide challenge decreased mRNA expression of key genes controlling the transmethylation and Met regeneration pathways, which was not prevented by Met supplementation. The data suggest that bovine hepatocyte cultures can be used as a bio-

Received March 24, 2017.

Accepted May 29, 2017.

${ }^{1}$ Corresponding author: heather.white@wisc.edu logical model to study the inflammatory cascade via an LPS challenge. Supplementation of Met prevents the LPS-induced hepatocyte cytokine expression and is associated with elevated intracellular GSH concentration. Key words: glutathione, interleukin, lipopolysaccharide

\section{INTRODUCTION}

Inflammation is an adaptive response triggered by stimuli such as infection and tissue injury and is a key feature in both infectious diseases and metabolic disorders across species (Hotamisligil, 2006; Medzhitov, 2008). Periparturient dairy cows experience depressed feed intake, negative energy balance, substantial metabolic and endocrine changes, and immunosuppression and therefore have greatly increased susceptibility to infectious and metabolic disease (Mallard et al., 1998; Drackley, 1999; Hammon et al., 2006). In several species, the postpartum period has been linked to an inflammatory state characterized by elevated inflammatory and positive acute phase mediators in the blood. Almost all cows experience a certain extent of systemic inflammation during the transition to lactation (Bertoni et al., 2008; Sordillo et al., 2009; Bradford et al., 2015). Although effective inflammatory responses lead to rapid elimination of insults such as microbial pathogens without detrimental damage to the host tissues, uncontrolled inflammation in dairy cows plays a dominant role in several economically important diseases such as mastitis and metritis (Sordillo et al., 2009) and directly affects metabolic function and milk production (Ametaj et al., 2005; Yuan et al., 2013; Bradford et al., 2015). For example, a strong relationship between fatty liver and plasma inflammation mediators was reported in periparturient dairy cows (Ametaj et al., 2005).

Lipopolysaccharide is a major component of the outer cell membrane of gram-negative bacteria and is capable of inducing inflammation and the acute phase response (Berczi, 1998). Dairy cows are exposed to increased concentrations of LPS when fed diets that contain high proportions of grains such as barley (Em- 
manuel et al., 2008) or when the barrier function of the gut is decreased due to various dietary and environmental conditions (Bradford et al., 2015). Elevated ruminal LPS concentration in dairy cows leads to translocation of LPS into the peripheral circulation in dairy cows (Khafipour et al., 2009). In addition to the vital functions in metabolism, detoxification, and protein synthesis, the liver contributes to the production of circulating inflammatory cytokines and acute phase proteins (APP) in dairy cows (Vels et al., 2009; Jørgensen et al., 2012). Increased proinflammatory cytokines, including tumor necrosis factor ( $\mathbf{T N F} \boldsymbol{\alpha})$ and IL- 6 and IL-1, are the primary inducers of the production of APP such as serum amyloid A (SAA) and haptoglobin (HP) in the liver (Ramadori and Christ, 1999; Yoo and Desiderio, 2003). Global gene expression analysis on liver tissues from dairy cows with mastitis caused by intramammary LPS administration showed upregulation of hepatic $T N F \alpha, I L-6, I L-1 \beta, I L-10, H P$, and $S A A 3$ accompanied by increased expression of p65 subunit of nuclear factor $\kappa \mathrm{B}(N F K B)$ complex and its inhibitor (NFKBIA; Jiang et al., 2008). Kupffer cells in the liver have been believed to be the key player in mediating the LPS-induced inflammatory responses (Yoshioka et al., 1998); however, a recent study in mice indicated that LPS is rapidly taken up by the primary hepatocytes within $6 \mathrm{~h}$, and hepatocytes play a key role in clearing LPS from the circulation (Boyd et al., 2016). Based on this previous research, it is important to determine the role of hepatocytes in the absence of Kupffer cells in mediating the LPS-induced inflammatory responses in cattle.

Methionine (Met) and lysine (Lys) are the 2 most limiting AA for milk protein production in dairy cows fed typical corn-alfalfa forage-based diets (NRC, 2001). In addition, Met plays important roles in a variety of fundamental biologic processes (Finkelstein, 1990), and Met metabolism is a key connector and regulator for 2 major homeostatic systems: cellular redox buffering and methylation (Martinov et al., 2010). The major pathway for hepatic Met metabolism, the transmethylation-transsulfuration sequence, leads to synthesis of glutathione (GSH) and S-adenosyl Met (SAM), the major intracellular antioxidant and biological methyl donor, respectively (Finkelstein, 1990; Martinov et al., 2010). Dietary supplementation of rumen-protected Met to periparturient dairy cows fed Met-deficient diets increased hepatic synthesis of GSH and reduced blood concentrations of IL-6 and SAA (Osorio et al., 2014a). However, the effects of Met supplementation on modulating the inflammatory responses in the liver of dairy cows are not well known. In addition, Lys availability has been shown to influence the response of milk protein synthesis and milk volume by increasing Met supplementation in dairy cows. An approximate Met to Lys ratio of 1:3.0 in the MP has been recommended to optimize milk protein production (NRC, 2001). Data are lacking regarding the effects of controlling or altering the Met to Lys plasma concentration ratios on the responses of other biological reactions to increasing concentrations of Met.

The objectives of the current study were (1) to establish an inflammation model with LPS challenge in primary neonatal bovine hepatocytes and (2) to characterize the effects of increasing concentration of Met and a maintained Met to Lys ratio on regulating intracellular GSH concentration, gene expression of pro- and anti-inflammatory cytokines, APP, and key enzymes for Met metabolism in neonatal bovine hepatocytes challenged with LPS. The hypothesis was that increasing Met concentration with a maintained Met to Lys ratio would increase GSH concentration, alleviate inflammatory responses, and prevent the impairment of Met metabolism caused by LPS challenge in primary neonatal bovine hepatocytes.

\section{MATERIALS AND METHODS}

\section{Hepatocyte Monolayer Preparation and Culture}

Four Holstein bull calves less than $7 \mathrm{~d}$ of age $(48 \pm$ $6 \mathrm{~kg}$ of BW) were used as hepatocyte donor animals. All experimental procedures involving animals were approved by the University of Wisconsin-Madison College of Agricultural and Life Sciences Animal Care and Use Committee. The caudate process was collected under anesthesia during a terminal surgery using pentobarbital sodium (Fatal-Plus, Vortech, Dearborn, MI). Primary hepatocytes were isolated via collagenase perfusion of the caudate process as described previously (Donkin and Armentano, 1993). Approximately $2.0 \times 10^{6}$ cells were seeded on 35 -mm Corning Primaria culture dishes (Fisher Scientific, Pittsburgh, PA) at a density of $2.0 \times 10^{5}$ cells $/ \mathrm{cm}^{2}$ with Dulbecco's Modified Eagle Medium (DMEM; 2902, Sigma, St. Louis, MO) containing 20\% fetal bovine serum (Sigma, St. Louis, MO) and 1\% antibiotic, antimycotic solution (Sigma). Cells were cultured at $37^{\circ} \mathrm{C}, 95 \%$ relative humidity, and $5 \% \quad \mathrm{CO}_{2}$. Four hours after seeding, the medium was aspirated and replaced with DMEM containing $10 \%$ fetal bovine serum and 1\% antibiotic, antimycotic solution. Cell viability was determined using the trypan blue exclusion method at the time of isolation. General cell health and morphology were monitored throughout the experiment using the ZOE Fluorescent Cell Imager (Bio-Rad Laboratories, Philadelphia, PA). 


\section{Cell Treatment}

Twenty-four hours after seeding, cells were approximately $80 \%$ confluent, and the medium was aspirated and replaced with Met-free DMEM containing 1\% bovine serum albumin (Merck Millipore, Billerica, MA) and $1 \%$ antibiotic, antimycotic solution, and plates were randomly assigned to treatments in triplicate. Treatments included 0,10 , or $40 \mu M$ DL-Met added to Met-free media containing $100 \mu M$ Lys (0Met100Lys, 10Met100Lys, or 40Met100Lys) and $10 \mu \mathrm{M}$ DLMet added to Met-free media containing $25 \mu M$ Lys (10Met25Lys). Both 40Met100Lys and 10Met25Lys had a Met to Lys ratio of 1:2.5, and 10Met100Lys had a Met to Lys ratio of 1:10. Cells were exposed to each treatment in triplicate for $16 \mathrm{~h}$ before challenge with either 0 or $100 \mathrm{ng} / \mathrm{mL}$ of LPS (Escherichia coli O111: B4, Sigma) for $8 \mathrm{~h}$. Hepatocytes that received 0Met100Lys served as an experimental control and were not challenged with LPS.

\section{GSH and Hydrogen Peroxide Quantification}

Cell culture medium was collected from each well, and each triplicate was pooled for quantification of hydrogen peroxide $\left(\mathrm{H}_{2} \mathrm{O}_{2}\right)$ using the Hydrogen Peroxide Cell-Based Assay Kit (Cayman, Ann Arbor, MI) following the manufacturer's instructions. Cells were then lysed by adding $450 \mu \mathrm{L}$ of cell-based assay lysis buffer (Cayman) to each well and incubating with gentle shaking on an orbital shaker for 15 min at room temperature. Cell lysates were collected into microcentrifuge tubes (Hauppauge, NY) and centrifuged at $113 \times g$ for $10 \mathrm{~min}$ at $4^{\circ} \mathrm{C}$. The supernatants were collected, and each triplicate was then pooled and quantified for GSH using the Cell-Based Glutathione Detection Kit (Cayman) according to the manufacturer's instructions.

\section{RNA Extraction and Real-Time Reverse Transcriptase PCR}

Cells were harvested in $0.5 \mathrm{~mL}$ of Trizol reagent (Life Technologies, Carlsbad, CA) and stored at $-80^{\circ} \mathrm{C}$ until RNA analysis. Total RNA was isolated using Trizol reagent following the manufacturer's instruction. Samples were quantified and quality was interrogated by absorbance using a Synergy Hybrid Spectrophotometer (BioTek, Winooski, VT). Each triplicate was pooled by equal quantity and further purified using the RNeasy Mini Kit (Qiagen, Thousand Oaks, CA). A total of $1.0 \mu \mathrm{g}$ of purified RNA sample was reverse transcribed to cDNA using iScript reverse transcriptase (Bio-Rad Laboratories). Gene expression was quantified with real-time PCR using SsoFast EvaGreen supermix (Bio-
Rad Laboratories) and primers shown in Table 1. A cDNA pool was generated from an equivalent quantity of cDNA from each sample. A 1:4 dilution series of the cDNA pool was used to generate the standard curve. A no template control (water as a template) and no reverse transcription control (RNA pool as a template) were included in the real-time PCR analysis. Primers were evaluated, and a single PCR product was verified using the following protocol: 1 cycle at $95^{\circ} \mathrm{C}$ for $3 \mathrm{~min}$; 45 cycles at $95^{\circ} \mathrm{C}$ for $5 \mathrm{~s}$ and $55^{\circ} \mathrm{C}$ for $5 \mathrm{~s}$; and a melt curve from 65 to $95^{\circ} \mathrm{C}$ by $0.5^{\circ} \mathrm{C}$ increments for $3 \mathrm{~s}$. All standards, controls, and samples were amplified in triplicate using the following reaction: 1 cycle at $95^{\circ} \mathrm{C}$ for 3 min, 45 cycles at $95^{\circ} \mathrm{C}$ for $5 \mathrm{~s}$, and $55^{\circ} \mathrm{C}$ for $5 \mathrm{~s}$. Efficiencies of all PCR reactions were between 90 and $110 \%$ based on standard curve analysis. The quantification cycle data were transformed to starting quantity (SQ) data with Bio-Rad CFX Manager Software (version 3.1, Bio-Rad Laboratories) based on standard curves. The SQ for the 5 standards (1:4 dilutions of the cDNA pool) was defined as $0.25,0.0625,0.0156,0.0039$, and 0.00098 . The mRNA abundance of each target gene was calculated as the SQ of the target gene normalized to the arithmetic mean SQ of 3 reference genes: $18 S$, ribosomal protein S9 (RPS9), and $\alpha$-1-microglobulin/ bikunin precursor $(A M B P)$. The lack of differences in the expression of the reference genes among experimental treatments was verified.

\section{Statistical Analysis}

All experiments were conducted in 4 separate cell preparations from 4 calves using 3 replicates per treatment. Normality was interrogated with the UNIVARIATE procedure of SAS (version 9.3, SAS Institute Inc., Cary, NC), and normal distribution of residuals was confirmed. Data were analyzed using the MIXED procedure of SAS. One-way ANOVA was performed using a model that included the fixed effect of treatment and random effect of cell preparation. Dunnett's test was used for comparisons between each treatment and 0Met100Lys in the absence of LPS. The effect of the combination of each Met and Lys concentration is referred to as MetLys. Preplanned orthogonal contrasts were conducted to determine the effect of LPS challenge within each MetLys treatment. The comparisons included 10Met100Lys $+0 \mathrm{ng} / \mathrm{mL}$ of LPS versus 10Met100Lys $+100 \mathrm{ng} / \mathrm{mL}$ of LPS, 40Met100Lys + $0 \mathrm{ng} / \mathrm{mL}$ of LPS versus 40Met100Lys $+100 \mathrm{ng} / \mathrm{mL}$ of LPS, and 10Met25Lys $+0 \mathrm{ng} / \mathrm{mL}$ of LPS versus 10 Met25Lys $+100 \mathrm{ng} / \mathrm{mL}$ of LPS. Data are reported as least squares means and standard errors. Statistical significance was declared at $P \leq 0.05$, and tendencies were declared at $0.05<P \leq 0.10$. 


\section{RESULTS}

\section{Met Supplementation Increases Intracellular GSH Concentration}

There was an overall difference $(P<0.01)$ in GSH concentration among the treatments (Figure 1A). In the absence of LPS challenge, intracellular GSH concentration in cells receiving 40Met100Lys was greater $(P<0.05)$ than that in cells receiving 0Met100Lys, whereas it was not different $(P>0.10)$ in cells receiving 10Met100Lys or 10Met25Lys compared with 0Met100Lys. Contrast analysis indicated that LPS stimulation decreased $(P<0.01)$ and tended to decrease $(P=0.10)$ the GSH concentration for 40Met100Lys and 10Met100Lys, respectively. Concentration of $\mathrm{H}_{2} \mathrm{O}_{2}$ released from the hepatocytes into the culture medium was not different $(P>0.10)$ among the treatments, indicating that neither MetLys treatment nor LPS altered $\mathrm{H}_{2} \mathrm{O}_{2}$ concentrations (Figure $1 \mathrm{~B}$ ).

\section{Met Supplementation Prevents LPS-Induced Proinflammatory Cytokine Expression}

There were overall differences $(P<0.05)$ in mRNA expression of $T N F \alpha$ (Figure 2A), IL-6 (Figure 2B), $I L-1 \beta$ (Figure 2C), and $I F N \gamma$ (Figure 2D) among the treatments. Expression of $T N F \alpha$ mRNA was consistently increased $(P<0.05)$ by LPS challenge across all the MetLys treatments. The mRNA abundance was increased $(P<0.01)$ for $I L-6$ (4-fold), $I L$ - $1 \beta$ (10-fold), and $I F N \gamma$ (8-fold) by LPS challenge in cells receiving 10Met100Lys. Importantly, 40Met100Lys prevented the LPS-induced increase in $I L-6, I L-1 \beta$, and $I F N \gamma$ mRNA expression, as shown by the lack of difference $(P>0.10)$ with or without LPS challenge in cells receiving 40Met100Lys. Partial preventive effects were observed for 10Met25Lys in terms of the lack of increase $(P>0.10)$ in $I L-1 \beta$ and $I F N \gamma$ mRNA in response to LPS challenge. However, it failed to prevent the LPSinduced increase in mRNA expression of $T N F \alpha$ and

Table 1. Primers used for target genes

\begin{tabular}{|c|c|c|c|}
\hline Gene & $\begin{array}{l}\text { GenBank } \\
\text { accession no. }\end{array}$ & Position $^{1}$ & Sequence $\left(5^{\prime}-3^{\prime}\right)$ \\
\hline \multirow[t]{2}{*}{$18 S$} & \multirow[t]{2}{*}{ NR_036642.1 } & $\mathrm{F}$ & ACCCATTCGAACGTCTGCCCTATT \\
\hline & & $\mathrm{R}$ & TCCTTGGATGTGGTAGCCGTTTCT \\
\hline \multirow[t]{2}{*}{ RPS9 } & \multirow[t]{2}{*}{ NM_001101152.2 } & $\mathrm{F}$ & CCTCGACCAAGAGCTGAAG \\
\hline & & $\mathrm{R}$ & CCTCCAGACCTCACGTTTGTTC \\
\hline \multirow[t]{2}{*}{$A M B P$} & \multirow[t]{2}{*}{ NM_173989.3 } & $\mathrm{F}$ & ACTGTCAAGCTCTATGGGCG \\
\hline & & $\mathrm{R}$ & CCTCTGTCGGGCATTGTGAA \\
\hline \multirow[t]{2}{*}{$I L-6$} & \multirow[t]{2}{*}{ NM_173923.2 } & $\mathrm{F}$ & GCGCATGGTCGACAAAATCT \\
\hline & & $\mathrm{R}$ & CAAATCGCCTGATTGAACCCA \\
\hline \multirow[t]{2}{*}{$T N F \alpha$} & \multirow[t]{2}{*}{ NM_173966.3 } & $\mathrm{F}$ & CAGGGCTCCAGAAGTTGCTT \\
\hline & & $\mathrm{R}$ & GCTTGAGAAGAGGACCTGAGT \\
\hline \multirow[t]{2}{*}{$I L-1 \beta$} & \multirow[t]{2}{*}{ NM_174093.1 } & $\mathrm{F}$ & CCTTCATTGCCCAGGTTTCTGA \\
\hline & & $\mathrm{R}$ & GCTGGATGTTTCCATCTCCCA \\
\hline \multirow[t]{2}{*}{$I F N \gamma$} & \multirow{2}{*}{ NM_174086.1 } & $\mathrm{F}$ & CAAATTCCGGTGGATGATCTGC \\
\hline & & $\mathrm{R}$ & GGCAGGAGGACCATTACGTT \\
\hline \multirow[t]{2}{*}{$I L-10$} & \multirow[t]{2}{*}{ NM_174088.1 } & $\mathrm{F}$ & CTTTAAGGGTTACCTGGGTTGC \\
\hline & & $\mathrm{R}$ & GCCTTGCTCTTGTTTTCGCA \\
\hline \multirow[t]{2}{*}{ NFKB1A } & \multirow[t]{2}{*}{ NM_001045868.1 } & $\mathrm{F}$ & AGGACGAGCTTCCCTACGAT \\
\hline & & $\mathrm{R}$ & CAGACCAGGCAGTGTGGTTA \\
\hline \multirow[t]{2}{*}{$H P$} & \multirow[t]{2}{*}{ NM_001040470.2 } & $\mathrm{F}$ & CCTATTACACACTGCGCACCT \\
\hline & & $\mathrm{R}$ & ATGATCCTCTGCACCTGGTC \\
\hline \multirow[t]{2}{*}{$S A A 3$} & \multirow[t]{2}{*}{ NM_181016.3 } & $\mathrm{F}$ & ACCTTTCCACGGGCATCATT \\
\hline & & $\mathrm{R}$ & AGTATTTGTCTGCACCCCTGT \\
\hline \multirow[t]{2}{*}{$C S E$} & \multirow[t]{2}{*}{ NM_001024567.1 } & $\mathrm{F}$ & CCTATCTCGCTGTCCACCAC \\
\hline & & $\mathrm{R}$ & GCCAAACTGTACTTAGCCCCA \\
\hline \multirow[t]{2}{*}{ GNMT } & \multirow[t]{2}{*}{ NM_001206116.1 } & $\mathrm{F}$ & GAGTGACCTGACCAAGGACG \\
\hline & & $\mathrm{R}$ & AGCCGGAACTTACTCAAGCC \\
\hline \multirow[t]{2}{*}{$M T R$} & \multirow[t]{2}{*}{ NM_001030298.1 } & $\mathrm{F}$ & GCCCCTGAAAGGCAACAATG \\
\hline & & $\mathrm{R}$ & CATCCGGTAGGCCAAGTGTT \\
\hline \multirow[t]{2}{*}{ BHMT } & \multirow[t]{2}{*}{ NM_001011679.1 } & $\mathrm{F}$ & TGGGGGCAAAAATGTCAAGAAG \\
\hline & & $\mathrm{R}$ & TCCGTCTCCGATGATGACCT \\
\hline$C B S$ & NM_001102000.2 & $\mathrm{F}$ & GAAGGTTCAGCCATCGGACC \\
\hline & & $\mathrm{R}$ & TGGCAGCGGTACTGGATCTG \\
\hline$M A T 1 A$ & NM_001046497.1 & $\mathrm{F}$ & GCCTGTGAGACGGTGTGTAA \\
\hline & & $\mathrm{R}$ & TAGCCAAACATCAGCCCCTG \\
\hline
\end{tabular}

${ }^{1} \mathrm{~F}=$ forward primer; $\mathrm{R}=$ reverse primer. 
$I L-6$, which had increased $(P<0.05)$ and a tendency for increased $(P=0.10)$ expression, respectively, with LPS challenge.

\section{Met Supplementation Prevents LPS-Induced Expression of NFKB1A and SAA3}

Among the treatments, there was a difference $(P<$ $0.01)$ in mRNA expression of the transcription factor NFKB1A (Figure 3A) and no difference $(P>0.10)$ in the anti-inflammatory cytokine $I L-10$ (Figure 3B).

A

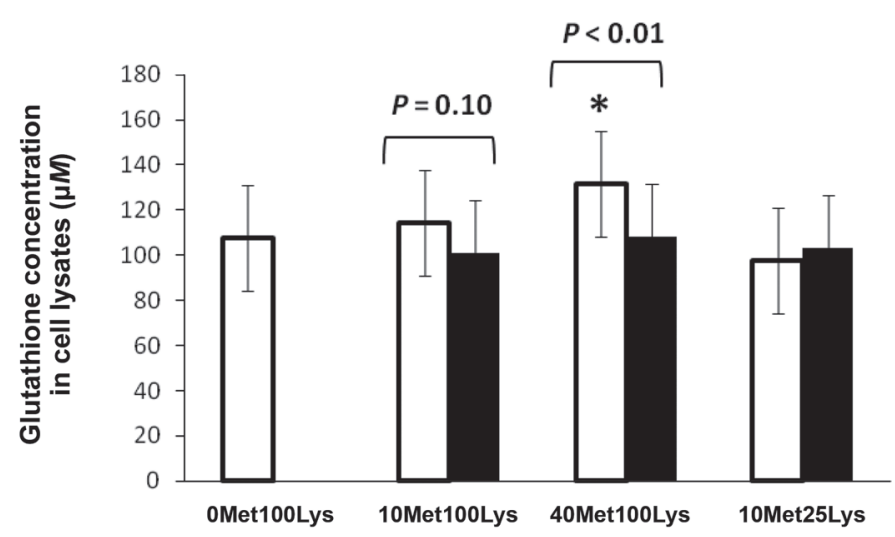

B

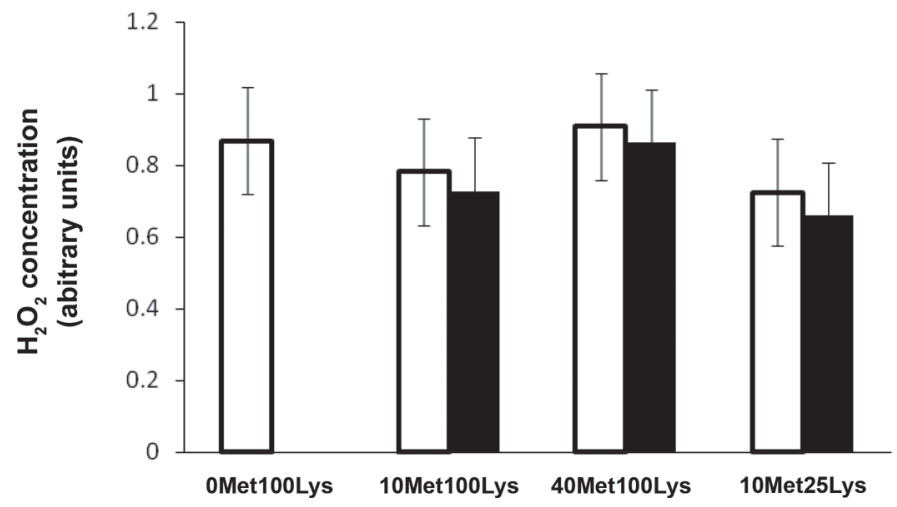

Figure 1. Effect of DL-methionine (Met) with maintained Met-toLys ratio on intracellular glutathione concentration (A) and hydrogen peroxide $\left(\mathrm{H}_{2} \mathrm{O}_{2}\right)$ concentration (B) in the culture media in primary neonatal bovine hepatocytes challenged with LPS. Cultured primary neonatal bovine hepatocytes were exposed to the 0Met100Lys $(0 \mu M$ Met and $100 \mu M$ Lys), 10Met100Lys (10 $\mu M$ Met and $100 \mu M$ Lys), 40Met100Lys (40 $\mu M$ Met and $100 \mu M$ Lys), or 10Met25Lys $(10 \mu M$ Met and $25 \mu \mathrm{MLys}$ ) treatments for $16 \mathrm{~h}$ before challenge with 0 (open bar) or 100 (solid bar) $\mathrm{ng} / \mathrm{mL}$ of LPS for $8 \mathrm{~h}$. Hepatocytes receiving 0Met100Lys served as the control in the absence of $100 \mathrm{ng} / \mathrm{mL}$ of LPS. Values are least squares means and standard errors $(\mathrm{n}=4$ cell preparations). The overall $P$-values for 1-way ANOVA analysis of Met and Lys treatment are presented at the top right of each panel. Brackets indicate significant difference $(P<0.05)$ between 0 and 100 $\mathrm{ng} / \mathrm{mL}$ of LPS within the Met and Lys treatment. The asterisk indicates significant difference $(P<0.05)$ between the labeled treatment and 0Met100Lys.
There was a tendency $(0.05<P \leq 0.10)$ for difference in $S A A 3$ (Figure $3 \mathrm{C}$ ) but no difference $(P>0.10)$ in $H P$ (Figure 3D). The mRNA abundance was increased for NFKB1A $(P<0.01)$ and SAA3 $(P<0.05)$ by LPS challenge in cells receiving 10Met100Lys. The treatments 40Met100Lys and 10Met25Lys prevented the LPS-induced increase in NFKB1A and SAA3 mRNA expression, as shown by the lack of differences $(P>$ $0.10)$ either with or without LPS challenge in cells receiving these 2 MetLys treatments.

\section{Met Does Not Prevent LPS-Impaired Expression of Key Genes for Met Metabolism}

Among the treatments, there were overall differences $(P<0.05)$ in mRNA expression of Met adenosyltransferase 1A (MAT1A; Figure 4A), glycine $N$-methyltransferase (GNMT; Figure 4B), and betainehomocysteine methyltransferase (BHMT; Figure 4C) and no differences $(P>0.10)$ in 5-methyltetrahydrofolate-homocysteine methyltransferase (MTR; Figure $4 \mathrm{D})$, cystathionine $\beta$-synthase $(C B S$; Figure $4 \mathrm{E})$, and cystathionase $(C S E$, Figure $4 \mathrm{~F})$. Cells challenged by LPS tended $(0.05<P \leq 0.10)$ to have lower expression of MAT1A within each MetLys treatment. Expression of GNMT mRNA was reduced by LPS challenge in cells receiving 10Met100Lys and 40Met100Lys and tended to be reduced $(P=0.06)$ in cells receiving 10Met25Lys. Compared with the Met-free control (0Met100Lys), expression of BHMT mRNA was decreased $(P<0.05)$ by Met supplementation in the absence of LPS, was further decreased $(P<0.05)$ by LPS challenge in cells receiving 10Met100Lys and 10Met25Lys, and tended to be decreased $(P=0.07)$ by LPS challenge in cells receiving 40Met100Lys.

\section{DISCUSSION}

Methionine and Lys are 2 of the most limiting AA for milk protein production in dairy cows fed typical corn-alfalfa forage-based diets (NRC, 2001). To examine the role and metabolism of Met during an inflammatory challenge in the present study, 0Met100Lys served as an experimental control; the 10Met100Lys and 40Met100Lys treatments were chosen to mimic serum Met concentration in cows fed diets deficient in or supplemented with Met, respectively. For example, dietary supplementation of rumen-protected Met (0 vs. $72 \mathrm{~g} / \mathrm{d}$ ) increased arterial Met concentrations (25 vs. 40 $\mu M)$ with Lys concentration of approximately $100 \mu M$ in early-lactation dairy cows (Berthiaume et al., 2006). In addition, the 10Met25Lys treatment had a similar Met to Lys ratio (1:2.5) as the 40Met100Lys treatment and thus served as a control for the Met to Lys ratio. 
It is important to note that the limited Lys concentration $(25 \mu M)$ used to maintain the Met to Lys ratio is significantly lower than the physiological concentration of $100 \mu M$ in lactating dairy cows (Berthiaume et al., 2006).

\section{LPS-Induced Inflammatory Responses}

The liver contributes to circulating inflammatory cytokines and plays a critical role in the acute phase response during infectious disease such as LPS-induced mastitis in dairy cows (Jiang et al., 2008; Vels et al.,
2009). It was reported that the Kupffer cells (liver tissue resident macrophages), not hepatocytes, are the main targets of LPS and sources of cytokine production during inflammation (Ma et al., 2009). However, several recent studies demonstrated that human hepatocytes responded to LPS directly by inducing $T N F \alpha, I L-6$, and $I L-1 \beta$ mRNA expression and SAA synthesis without the mediation of Kupffer cells (Migita et al., 2004; Jeschke et al., 2008). Therefore, it is not surprising to observe significant LPS-induced increases in mRNA expression of the proinflammatory cytokines, including $T N F \alpha, I L-6, I L-1 \beta$, and $I F N \gamma$, in primary neonatal
A

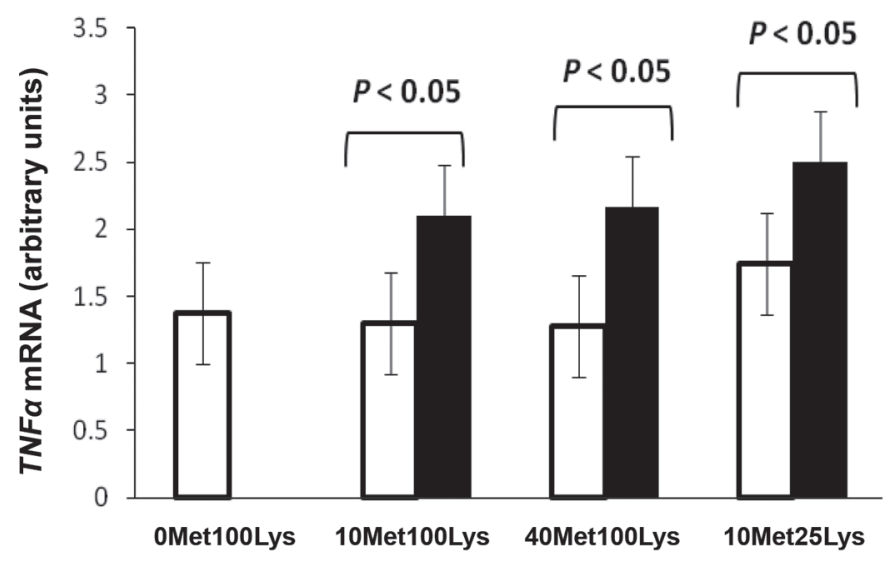

C

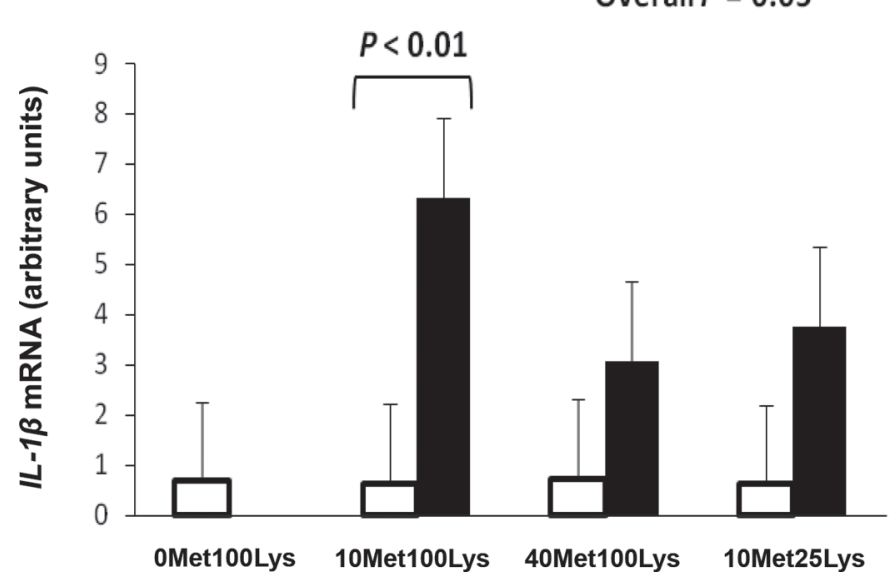

B

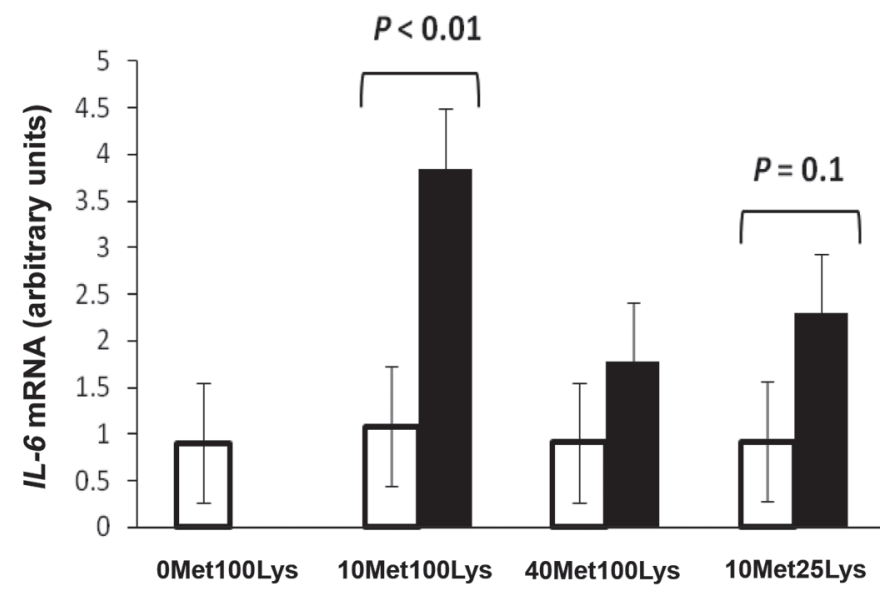

D

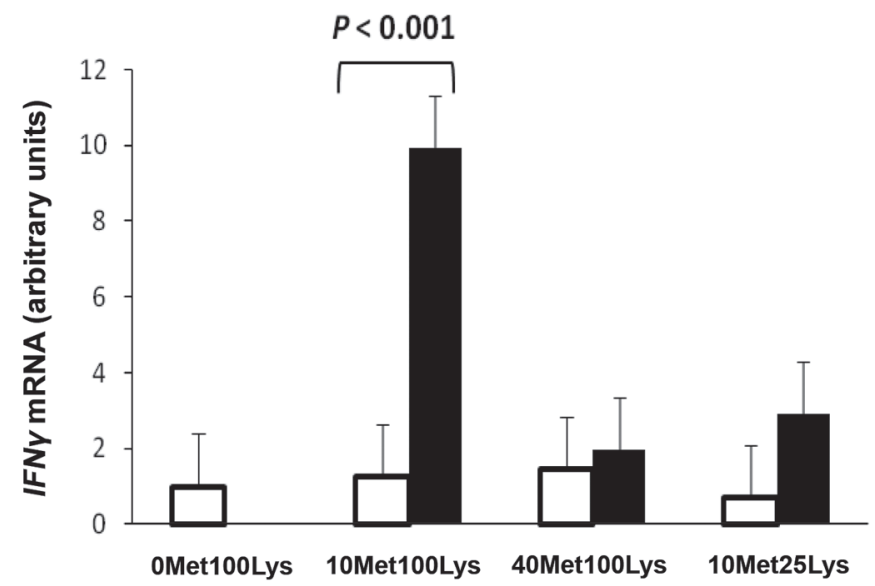

Figure 2. Effect of DL-methionine (Met) with maintained Met-to-Lys ratio on mRNA abundance of tumor necrosis factor (TNF $\alpha$; A) and proinflammatory cytokines $I L-6(\mathrm{~B}), I L-1 \beta(\mathrm{C})$, and $I F N \gamma(\mathrm{D})$ in primary neonatal bovine hepatocytes challenged with LPS. Cultured primary neonatal bovine hepatocytes were exposed to the 0Met100Lys ( $0 \mu M$ Met and $100 \mu M$ Lys), 10Met100Lys (10 $\mu M$ Met and $100 \mu M$ Lys), 40Met100Lys $(40 \mu M$ Met and $100 \mu M$ Lys), or 10Met25Lys (10 $\mu M$ Met and $25 \mu M$ Lys) treatments for 16 h before challenge with 0 (open bar) or 100 (solid bar) ng/mL of LPS for $8 \mathrm{~h}$. Hepatocytes receiving 0Met100Lys served as the control in the absence of $100 \mathrm{ng} / \mathrm{mL}$ of LPS. Values are least squares means and standard errors $(\mathrm{n}=4$ cell preparations). The overall $P$-values for 1 -way ANOVA analysis of Met and Lys treatment are presented at the top right of each panel. Brackets indicate significant difference $(P<0.05)$ between 0 and $100 \mathrm{ng} / \mathrm{mL}$ of LPS within the Met and Lys treatment. 
A

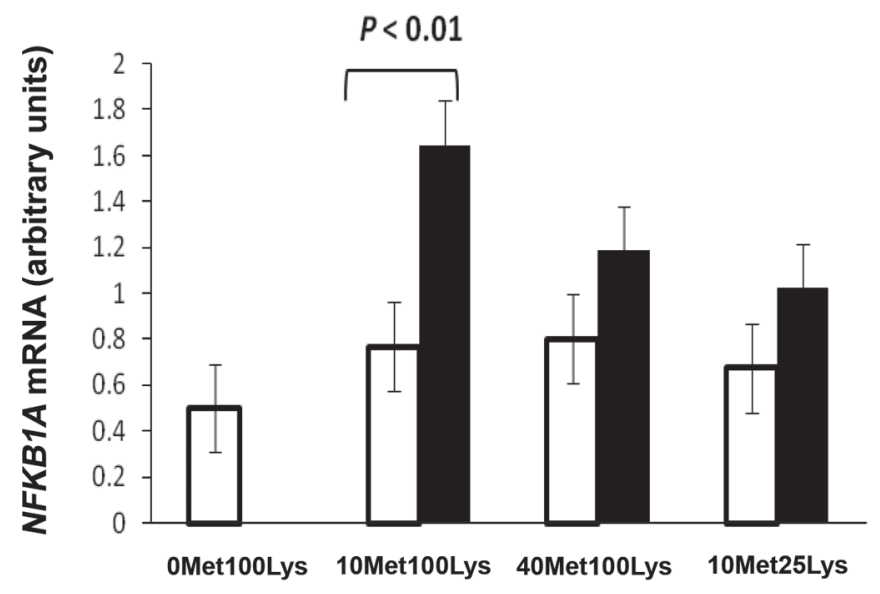

$\mathrm{C}$

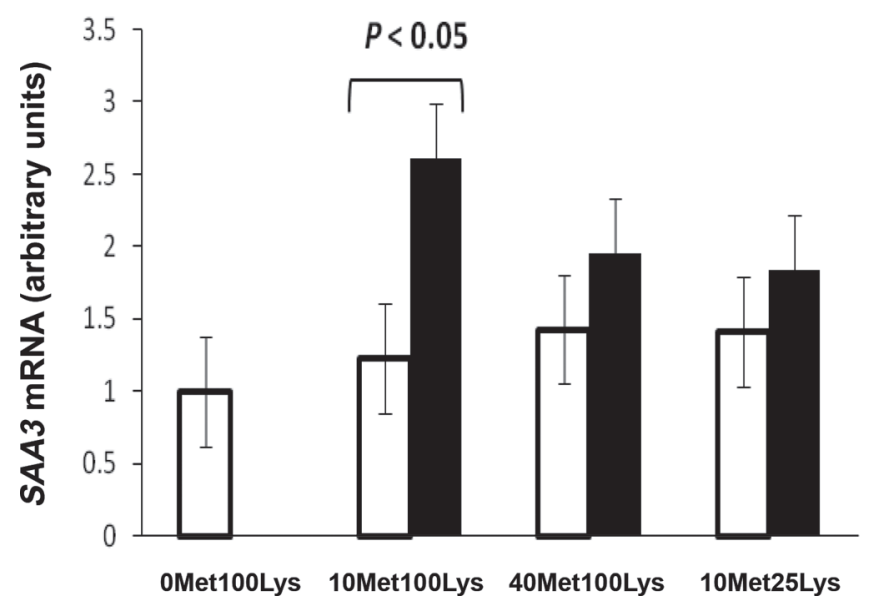

B

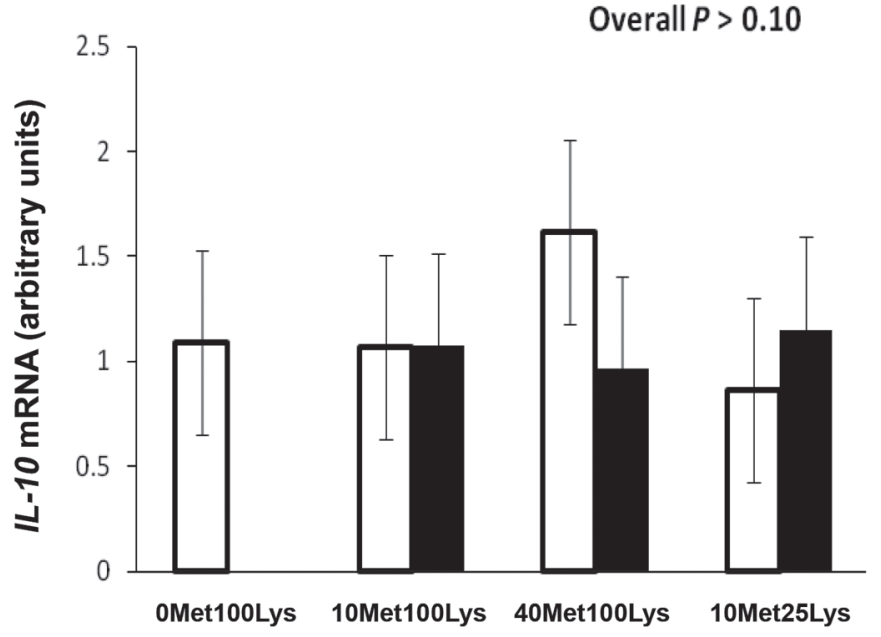

D

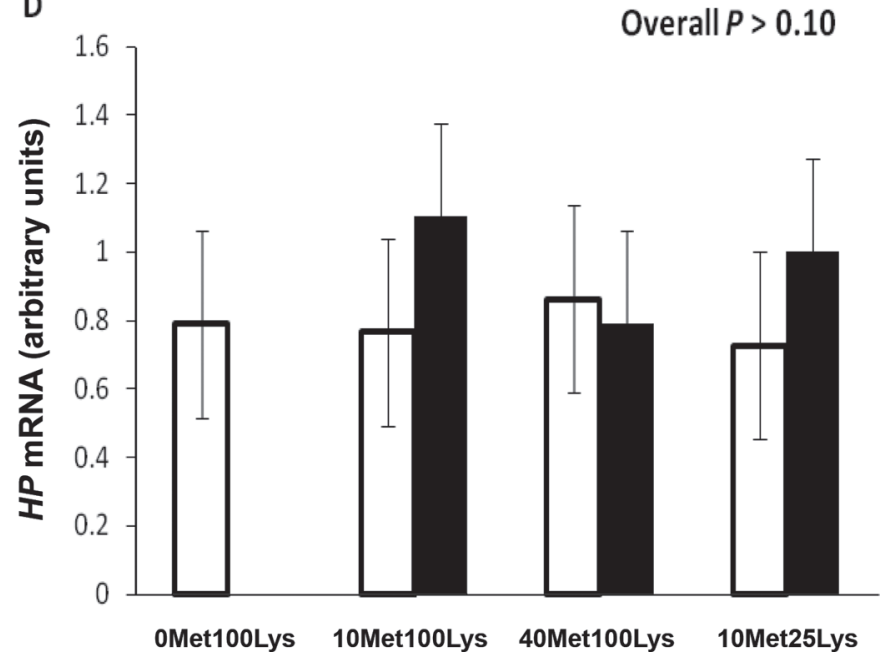

Figure 3. Effect of DL-methionine (Met) with maintained Met-to-Lys ratio on mRNA abundance of the transcription factor nuclear factor $\kappa \mathrm{B}$ inhibitor $(N F K B 1 A$; A), the anti-inflammatory cytokine $I L-10(\mathrm{~B})$, and the acute response proteins serum amyloid A (SAA3; C) and haptoglobin $(H P$; D) in primary neonatal bovine hepatocytes challenged with LPS. Cultured primary neonatal bovine hepatocytes were exposed to the 0Met100Lys $(0 \mu M$ Met and $100 \mu M$ Lys), 10Met100Lys $(10 \mu M$ Met and $100 \mu M$ Lys), 40Met100Lys (40 $\mu M$ Met and $100 \mu M$ Lys), or 10Met25Lys (10 $\mu \mathrm{M}$ Met and $25 \mu \mathrm{M}$ Lys) treatments for $16 \mathrm{~h}$ before challenge with 0 (open bar) or 100 (solid bar) ng/mL of LPS for $8 \mathrm{~h}$. Hepatocytes receiving 0Met100Lys served as the control in the absence of $100 \mathrm{ng} / \mathrm{mL}$ of LPS. Values are least squares means and standard errors ( $\mathrm{n}=4$ cell preparations). The overall $P$-values for 1 -way ANOVA analysis of Met and Lys treatment are presented at the top right of each panel. Brackets indicate significant difference $(P<0.05)$ between 0 and $100 \mathrm{ng} / \mathrm{mL}$ of LPS within the Met and Lys treatment.

bovine hepatocytes receiving 10Met100Lys. As a defensive mechanism, numerous APP such as HP and SAA are produced by the liver during the acute phase response, which is mainly mediated by proinflammatory cytokines, including TNF $\alpha$, IL-6, and IL-1 $\beta$ (Murata et al., 2004). In the present study, even though $H P$ mRNA expression was not altered, SAA3 mRNA expression was increased in cells receiving 10Met100Lys, indicating that the bovine hepatocytes initiated the acute phase response following LPS challenge. Our results are consistent with the previous observation that plasma concentration of SAA, but not HP, was increased during the systemic inflammation stimulated by increased ruminal LPS content via feeding high proportions of barley grain in lactating dairy cows (Emmanuel et al., 2008).

The LPS-induced increase in NFKB1A mRNA in hepatocytes receiving 10Met100Lys provides additional evidence of the important role of NFKB signaling in mediating LPS-stimulated inflammation in hepatocytes. In vivo, increased expression of NFKB1A mRNA was also accompanied by the increased mRNA expression 

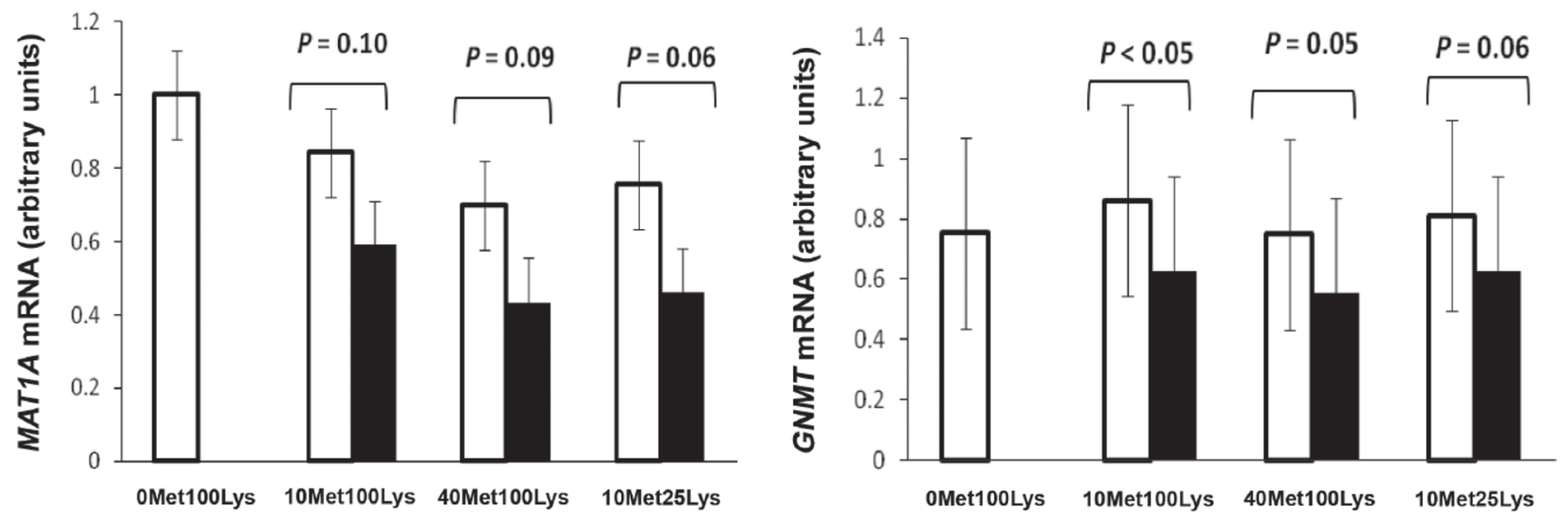

C

D
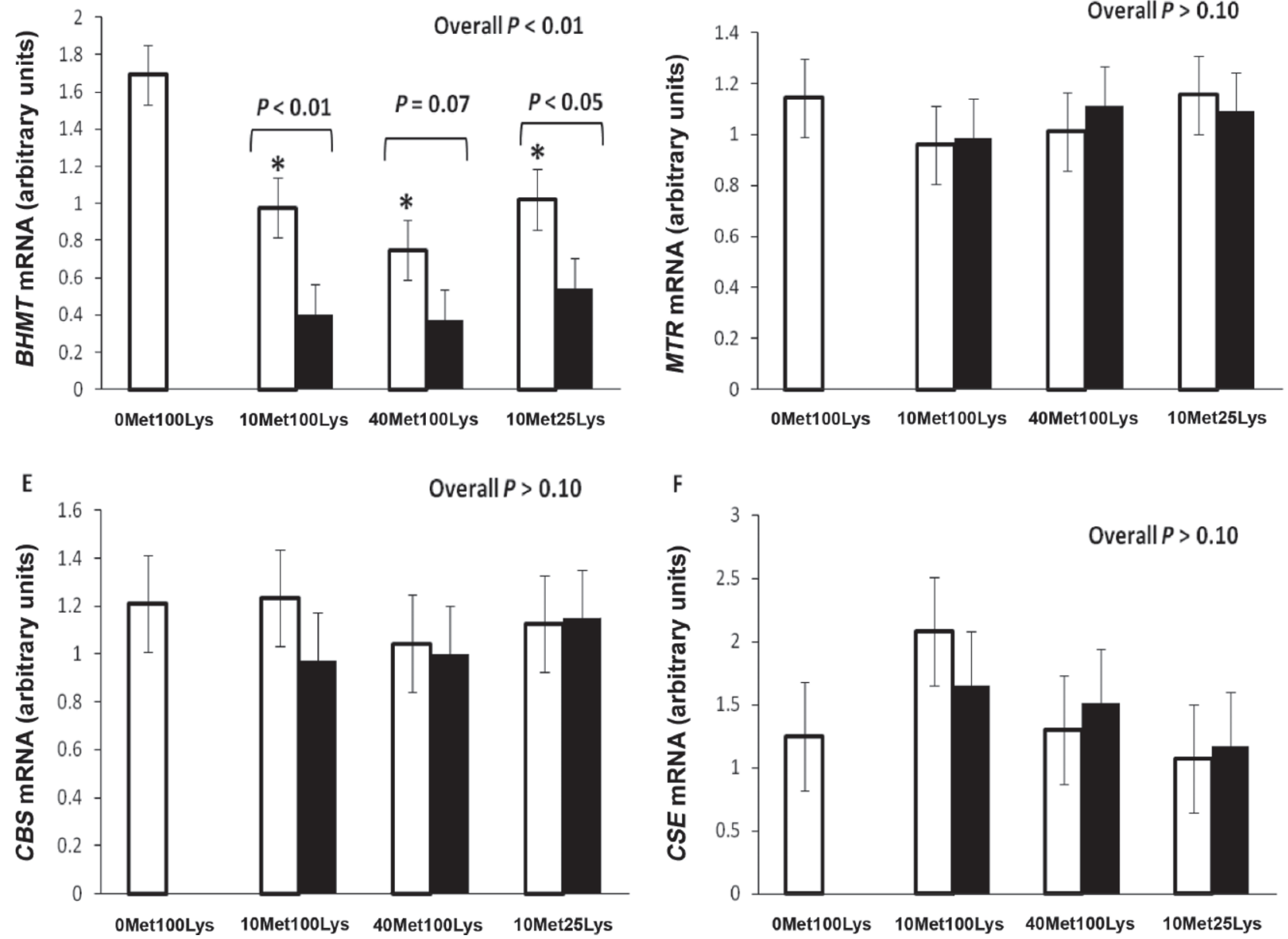

Figure 4. Effect of DL-methionine (Met) with maintained Met-to-Lys ratio on methionine adenosyltransferase $1 \mathrm{~A}$ (MAT1A; A), glycine $N$-methyltransferase (GNMT: B), betaine-homocysteine methyltransferase (BHMT: C), 5-methyltetrahydrofolate-homocysteine methyltransferase $(M T R ; \mathrm{D})$, cystathionine $\beta$-synthase $(C B S ; \mathrm{E})$, and cystathionase $(C S E ; \mathrm{F}) \mathrm{mRNA}$ abundance in primary neonatal bovine hepatocytes challenged with LPS. Cultured primary neonatal bovine hepatocytes were exposed to the 0Met100Lys $(0 \mu M$ Met and $100 \mu M$ Lys $), 10 \mathrm{Met} 100 \mathrm{Lys}$ $(10 \mu M$ Met and $100 \mu M$ Lys), 40Met100Lys (40 $\mu M$ Met and $100 \mu M$ Lys), or 10Met25Lys (10 $\mu M$ Met and $25 \mu M$ Lys) treatments for 16 $\mathrm{h}$ before challenge with 0 (open bar) or 100 (solid bar) $\mathrm{ng} / \mathrm{mL}$ of LPS for $8 \mathrm{~h}$. Hepatocytes receiving 0Met100Lys served as the control in the absence of $100 \mathrm{ng} / \mathrm{mL}$ of LPS. Values are least squares means and standard errors $(\mathrm{n}=4$ cell preparations). The overall $P$-values for 1 -way ANOVA analysis of Met and Lys treatment are presented at the top right of each panel. Brackets indicate significant difference $(P<0.05)$ between 0 and $100 \mathrm{ng} / \mathrm{mL}$ of LPS within the Met and Lys treatment. The asterisk indicates significant difference $(P<0.05)$ between the labeled treatment and 0Met100Lys. 
of proinflammatory cytokines in the liver of dairy cows with mastitis caused by intramammary LPS challenge (Jiang et al., 2008). The NFKB1A gene encodes NFKB inhibitory protein IKB, which is closely associated with the transcription factor NFKB in the cytoplasm of the cell. Upon stimulation, the phosphorylation and degradation of IKB frees NFKB, which can translocate into the nucleus to activate the expression of the target genes (Gloire et al., 2006). It has been indicated that the NFKB/Rel family of transcription factors mediates the LPS-activated transcription of a variety of genes, including $T N F \alpha$ and $I L-6$ (Kuprash et al., 1995; Galien et al., 1996).

Oxidants such as $\mathrm{H}_{2} \mathrm{O}_{2}$ enhance the production of proinflammatory cytokines, including IL-1, IL-8, and TNF, by activating the NFKB signaling in response to inflammatory stimuli (Grimble, 1994). Hydrogen peroxide is a reactive oxygen species (ROS), which has been widely recognized to act as a second messenger in signal transduction and regulation of gene expression in several cell types under different biological conditions (Gloire et al., 2006). It has been demonstrated that LPS-induced production of proinflammatory cytokines is mediated by ROS production in mouse immune cells (Matsuzawa et al., 2005). The lack of changes in ROS concentration in the current study may indicate that the LPS-induced expression of proinflammatory cytokines and NFKB1A mRNA in neonatal bovine hepatocytes is not mediated by ROS; however, it is important to note that intracellular ROS was not measured in the current study. Mitochondria are the main source of ROS production in hepatocytes (Jaeschke and Mitchell, 1989), and produced ROS can be either released into the extracellular environment or accumulated within cells, depending on the cell type (Uy et al., 2011). To fully understand the lack of change in released ROS during LPS-induced inflammation, the relationship between intracellular and released ROS and intracellular antioxidants such as GSH needs to be further examined.

In a previous study, liver slices taken from early- and mid-lactation dairy cows were incubated in vitro and challenged with LPS to induce hepatic inflammation, and increased mRNA expression of $T N F \alpha, H P$, and SAA2 was observed (Garcia et al., 2015). Hepatic expression of cytokines and APP was increased in mid-lactation dairy cows with elevated LPS concentration in the rumen and hepatic veins via feeding a high-concentration diet (Chang et al., 2015). Increased mRNA expression of proinflammatory cytokines and $S A A 3$ was observed in the liver of dairy cows with mastitis caused by intramammary LPS challenge (Jiang et al., 2008). Primary neonatal bovine hepatocyte cell culture has been proven to be a useful model for study- ing underlying regulatory mechanisms because the cultured cells maintain hormone, substrate, and pathway responsiveness (Donkin and Armentano, 1993, 1994; Donkin et al., 1997). The current work demonstrates that an inflammation model with LPS challenge in primary neonatal bovine hepatocytes can be successfully established. Neonatal bovine hepatocytes responded similarly to LPS challenge compared with previous in vivo and in situ LPS challenges. The advantage of an in vitro cell culture model is the reduction of in vivo confounders, including differences in feed intake, nutrient status, and hormone concentrations. By mimicking actual physiological metabolite concentrations, our model is valuable for studying the hepatic responses to nutrients of interest during inflammation in dairy cows.

\section{Anti-Inflammatory Effect of Met Supplementation}

In contrast to the 10Met100Lys treatment, 40Met100Lys prevented the LPS-induced increases in $I L-6$, $I L-1 \beta, I F N \gamma, N F K B 1 A$, and $S A A 3$ mRNA expression, suggesting an anti-inflammatory effect of Met supplementation in neonatal bovine hepatocytes. The greater intracellular GSH concentration in hepatocytes receiving 40Met100Lys compared with 0Met100Lys in the absence of LPS challenge further indicates that the anti-inflammatory effect might be mediated by increasing GSH production. Our results are consistent with an in vivo study that showed that Met supplementation to periparturient dairy cows decreased blood concentration of IL-6 and SAA, but not HP, accompanied with increased hepatic GSH concentration (Osorio et al., 2014a). Similarly, GSH concentration in rat liver was positively correlated with dietary Met intake, and supplementation of Met to a low-protein diet led to elevated GSH concentration in the absence of inflammation (Hunter and Grimble, 1997). This relationship has also been demonstrated in the inverse direction, with decreased mitochondrial and hepatic GSH and increased neutrophil infiltration and inflammation in mice fed a Met-deficient diet (Caballero et al., 2010).

Glutathione is a major endogenous antioxidant that plays important roles not only in defending against oxidative stress but also in regulation of redox signaling, cell proliferation, apoptosis, immune function, and detoxification of xenobiotics (Lu, 2013). Exogenous GSH administration is effective in reducing LPS-stimulated systemic inflammatory response and mortality in rats (Sun et al., 2006). Sordillo et al. (2009) suggested a relationship between lower antioxidant capacity and elevated proinflammatory status, which determined the susceptibility of peripartal dairy cows to disease. Cytokine production is influenced by GSH synthesis, which 
is further influenced by dietary intake of sulfur AA, including Met and cysteine (Grimble, 1994). The liver is a key organ that synthesizes GSH and regulates GSH homeostasis (Lu, 2013). Cysteine can be synthesized from Met through the hepatic transmethylation-transsulfuration sequence (Finkelstein, 1990). The decrease in GSH concentration in response to LPS challenge in the current study was not surprising because decreasing GSH concentration by LPS challenge in liver has been commonly observed and is attributed to several mechanisms, including oxidative stress (Zhang et al., 2000), enhanced sinusoidal GSH efflux (Jaeschke, 1992), and inhibition of the activity of key enzymes for GSH synthesis (Ko et al., 2008). Similar to the observation in mice in which an LPS-induced decrease in hepatic GSH was not prevented by the administration of a cysteine precursor (Payabvash et al., 2006), the reduced GSH concentration in the current study was not prevented by Met supplementation. However, at the expense of GSH, increased Met concentration was able to prevent the LPS-induced expression of the inflammatory mediators, which may explain the beneficial effects of Met supplementation on improving immunometabolic status observed in periparturient dairy cows (Osorio et al., 2014a).

It is interesting that 10Met25Lys exerts, in part, an anti-inflammatory effect by preventing the LPS-induced increases in $I L-1 \beta, I F N \gamma, N F K B I A$, and $S A A 3 \mathrm{mRNA}$ expression despite the lack of effects on $I L-6$ mRNA expression and GSH concentration. This suggests that only part of the anti-inflammatory role of Met is mediated by GSH, given that amelioration of the induced inflammation (except for $I L-6$ ) was achieved without a change in GSH concentration in the 10Met25Lys treatment. Both the 10Met25Lys and 40Met100Lys treatments had a Met to Lys ratio of 1:2.5, which was designed to mimic the recommended Met to Lys ratio of $1: 2.8$ or $1: 3$ to optimize milk protein production in dairy cows (NRC, 2001). Lysine concentration influences the response of milk protein synthesis to increasing Met concentrations in dairy cows (NRC, 2001), and the current study further demonstrates that Met to Lys ratio also influences the potential anti-inflammatory effect of Met supplementation in the bovine hepatocytes. However, it is not realistic or advantageous to reduce Lys concentration from $100 \mu M$ to $25 \mu M$ considering the animal requirement for Lys. Additionally, supplementation of Met with a maintained Met to Lys ratio resulted in a more complete amelioration of the LPS effects than the low Met concentration with maintained Met to Lys ratio, which did not ameliorate the $I L-6$ increase. Taken together, this emphasizes the importance of supplementing Met to peripartum dairy cows to achieve the optimal Met to Lys ratio.

\section{Hepatic Met Metabolism During LPS Challenge and Met Supplementation}

The pathways for Met metabolism can be summarized by transmethylation, transsulfuration, and Met remethylation, which are regulated by the expression of several key genes (Finkelstein, 1990). The important metabolite of the first step of Met metabolism is SAM, the primary biological methyl donor. The conversion of Met to SAM is catalyzed by Met adenosyltransferase (MAT), an enzyme that has 3 distinct forms and is encoded by 2 different genes. The MAT1A gene is expressed exclusively in hepatic tissue and encodes MATI and MATIII, whereas the MAT2A gene is expressed mainly in fetal hepatocytes and extrahepatic tissues and encodes MATII (Mato et al., 2002). The tendency for reduced MAT1A mRNA expression in response to LPS challenge in bovine hepatocytes is in contrast to the observations in mice in which hepatic MAT1A mRNA was increased by LPS challenge (Ko et al., 2008). Differential hepatic regulation of MAT1A mRNA expression between rodents and ruminants has been demonstrated previously (Zhang et al., 2016). It is noteworthy that the enzyme activity of MATI/III is highly regulated posttranslationally (Mato et al., 2002). For example, despite the increased mRNA expression of MAT1A, MATI/III activity in mouse liver was inhibited by LPS challenge (Ko et al., 2008). Similarly, LPS challenge decreased hepatic MATI/III activity in rats (Lu et al., 2000). The posttranslational regulation of MATI/III in response to LPS challenge in neonatal bovine hepatocytes warrants further research.

Among all the SAM-dependent methyltransferases, GNMT is quantitatively the most important methyltransferase that catabolizes SAM while converting glycine into sarcosine in mammalian liver (Mato et al., 2008). The decreased expression of GNMT mRNA by LPS challenge in neonatal bovine hepatocytes is consistent with observations in mice in which both hepatic mRNA and protein expression of GNMT were decreased by LPS challenge (Ko et al., 2008). The decrease in total hepatic transmethylation flux caused by reduced GNMT expression cannot be compensated for by other hepatic methyltransferases (Mato et al., 2008). Indeed, decreased expression of GNMT results in reduced total transmethylation flux and accumulation of hepatic SAM concentration in humans (Mato et al., 2008). Similarly, increased hepatic SAM concentration in response to LPS challenge was observed in mice, which was attributed to decreased SAM utilization (Ko et al., 2008). Even though SAM concentration was not measured in the current study, the simultaneous decrease of MAT1A and GNMT mRNA expression by LPS challenge in the current study may lead to overall 
decreased transmethylation flux and aberrant methylation reactions. Indeed, a previous study showed that the upregulation of gene expression of cytokines and APP by LPS was attributable to altered DNA methylation in the liver of mid-lactation dairy cows (Chang et al., 2015).

Despite the changes in mRNA species associated with transmethylation by LPS challenge, there were no effects on the expression of the 2 genes involved in the transsulfuration pathway- $C B S$ and $C S E$ - that catalyze the 2-step reaction to form cysteine from homocysteine. Instead, expression of BHMT, which regenerates Met from homocysteine using a methyl group from betaine, was decreased by LPS challenge in neonatal bovine hepatocytes. Expression of BHMT mRNA was decreased by increasing concentration of Met in neonatal bovine hepatocytes, likely due to the decreased need for Met regeneration (Zhang et al., 2016; Chandler and White, 2017). Consistently, in the current study, Met supplementation also decreased BHMT mRNA expression compared with 0Met100Lys in the absence of LPS. In vivo, BHMT was not affected by dietary Met supplementation but was increased postpartum (Osorio et al., 2014b). In primary neonatal bovine hepatocytes, $B H M T$ was not altered by fatty acid supplementation, although expression of MAT1A, MTR, and MTHFR was decreased by fatty acid challenge, which may suggest an important role of $B H M T$ in maintaining Met metabolism during the transition period (Chandler and White, 2017). However, further inhibition of BHMT mRNA by LPS challenge may impair the normal Met regeneration process in neonatal bovine hepatocytes. Mediation of BHMT regulation at the time of calving, specifically with the confounders of elevated fatty acids and inflammatory stress, should be further examined in vivo.

Altered nutrient metabolism during LPS-induced inflammatory states has been previously observed in bovine liver. Hepatic gluconeogenesis was impaired by LPS challenge during in vitro incubation of liver slices collected from early- and mid-lactation dairy cows (Garcia et al., 2015), and expression of key hepatic gluconeogenic genes was downregulated in the liver of lactating dairy cows given intramammary LPS challenge (Jiang et al., 2008). In the current study, the decreased expression of MAT1A, GNMT, and BHMT by LPS challenge indicated that the hepatic Met metabolism and regeneration was impaired during LPSstimulated inflammation. Although the inflammatory response was ameliorated by Met supplementation, the decreased gene expression for Met metabolism by LPS was not prevented with Met supplementation, which may indicate decreased Met regeneration dur- ing inflammation and further exacerbation of the Met deficit during this period. Given that the periparturient period combines inflammatory stress and an increased requirement of Met, Met metabolism and interactions with inflammatory stress need to be further examined during the transition to lactation in dairy cows.

\section{CONCLUSIONS}

In conclusion, an inflammation model can be successfully established in primary neonatal bovine hepatocytes via LPS challenge, which parallels responses to an inflammatory challenge observed in vivo. Methionine supplementation protects against LPS-induced inflammation in neonatal bovine hepatocytes, which may be partially attributed to the ability of Met supplementation to enhance GSH production and thus the antioxidant defense. Beneficial effects observed with supplemental Met may also be partially attributed to maintaining a favorable Met to Lys ratio. Methionine metabolism in neonatal bovine hepatocytes is impaired during LPS challenge as shown by the decreased expression of several key genes, including MAT1A, GNMT, and BHMT.

\section{ACKNOWLEDGMENTS}

The authors thank Peter Crump (University of Wisconsin, Madison) for his assistance with the statistical analysis for this project. Funding for this research was provided by Adisseo (Alpharetta, GA).

\section{REFERENCES}

Ametaj, B. N., B. J. Bradford, G. Bobe, R. A. Nafikov, Y. Lu, J. W. Young, and D. C. Beitz. 2005. Strong relationships between mediators of the acute phase response and fatty liver in dairy cows. Can. J. Anim. Sci. 85:165-175.

Berczi, I. 1998. Neurohormonal host defense in endotoxin shock. Ann. N. Y. Acad. Sci. 840:787-802.

Berthiaume, R., M. C. Thivierge, R. A. Patton, P. Dubreuil, M. Stevenson, B. W. McBride, and H. Lapierre. 2006. Effect of ruminally protected methionine on splanchnic metabolism of amino acids in lactating dairy cows. J. Dairy Sci. 89:1621-1634.

Bertoni, G., E. Trevisi, X. Han, and M. Bionaz. 2008. Effects of inflammatory conditions on liver activity in puerperium period and consequences for performance in dairy cows. J. Dairy Sci. 91:33003310.

Boyd, J. H., J. A. Russell, K. Walley, and E. Topchiy. 2016. Lipopolysaccharide is cleared from the circulation by hepatocytes via the low density lipoprotein receptor. Am. J. Respir. Critical Care Med. 193:A2719.

Bradford, B. J., K. Yuan, J. K. Farney, L. K. Mamedova, and A. J. Carpenter. 2015. Invited review: Inflammation during the transition to lactation: New adventures with an old flame. J. Dairy Sci. 98:6631-6650.

Caballero, F., A. Fernández, N. Matías, L. Martínez, R. Fucho, M. Elena, J. Caballeria, A. Morales, J. C. Fernández-Checa, and C. García-Ruiz. 2010. Specific contribution of methionine and choline 
in nutritional nonalcholoic steatohepatitis: Impact on mitochondrial S-adenosyl-L-methionine and glutathione. J. Biol. Chem. 285:18528-18536.

Chandler, T. L., and H. M. White. 2017. Choline and methionine differentially alter methyl carbon metabolism in bovine neonatal hepatocytes. PLoS One 12:e0171080.

Chang, G., K. Zhang, T. Xu, D. Jin, J. Guo, S. Zhuang, and X. Shen. 2015. Epigenetic mechanisms contribute to the expression of immune related genes in the livers of dairy cows fed a high concentrate diet. PLoS One 10:e0123942.

Donkin, S. S., and L. E. Armentano. 1993. Preparation of extended in vitro cultures of bovine hepatocytes that are hormonally responsive. J. Anim. Sci. 71:2218-2227.

Donkin, S. S., and L. E. Armentano. 1994. Regulation of gluconeogenesis by insulin and glucagon in the neonatal bovine. Am. J. Physiol. 266:R1229-R1237.

Donkin, S. S., S. J. Bertics, and L. E. Armentano. 1997. Chronic and transitional regulation of gluconeogenesis and glyconeogenesis by insulin and glucagon in neonatal calf hepatocytes. J. Anim. Sci. 75:3082-3087.

Drackley, J. K. 1999. Biology of dairy cows during the transition period: The final frontier? J. Dairy Sci. 82:2259-2273.

Emmanuel, D. G. V., S. M. Dunn, and B. N. Ametaj. 2008. Feeding high proportions of barley grain stimulates an inflammatory response in dairy cows. J. Dairy Sci. 91:606-614.

Finkelstein, J. D. 1990. Methionine metabolism in mammals. J. Nutr. Biochem. 1:228-237.

Galien, R., H. F. Evans, and T. Garcia. 1996. Involvement of CCAAT/ enhancer-binding protein and nuclear factor-kappa B binding sites in interleukin-6 promoter inhibition by estrogens. Mol. Endocrinol. 10:713-722.

Garcia, M., B. J. Bequette, and K. M. Moyes. 2015. Hepatic metabolic response of Holstein cows in early and mid lactation is altered by nutrient supply and lipopolysaccharide in vitro. J. Dairy Sci. 98:7102-7114.

Gloire, G., S. Legrand-Poels, and J. Piette. 2006. NF-кB activation by reactive oxygen species: Fifteen years later. Biochem. Pharmacol. 72:1493-1505.

Grimble, R. F. 1994. Nutritional antioxidants and the modulation of inflammation: Theory and practice. New Horiz. 2:175-185.

Hammon, D. S., I. M. Evjen, T. R. Dhiman, J. P. Goff, and J. L. Walters. 2006. Neutrophil function and energy status in Holstein cows with uterine health disorders. Vet. Immunol. Immunopathol. 113:21-29.

Hotamisligil, G. S. 2006. Inflammation and metabolic disorders. Nature 444:860-867.

Hunter, E. A. L., and R. F. Grimble. 1997. Dietary sulphur amino acid adequacy influences glutathione synthesis and glutathione-dependent enzymes during the inflammatory response to endotoxin and tumour necrosis factor- $\alpha$ in rats. Clin. Sci. 92:297-305.

Jaeschke, H. 1992. Enhanced sinusoidal glutathione efflux during endotoxin-induced oxidant stress in vivo. Am. J. Physiol. 263:G60G68.

Jaeschke, H., and J. R. Mitchell. 1989. Mitochondria and xanthine oxidase both generate reactive oxygen species in isolated perfused rat liver after hypoxic injury. Biochem. Biophys. Res. Commun. 160:140-147.

Jeschke, M. G., D. Klein, W. E. Thasler, U. Bolder, H. Schlitt, K. Jauch, and T. S. Weiss. 2008. Insulin decreases inflammatory signal transcription factor expression in primary human liver cells after LPS challenge. Mol. Med. 14:11-19.

Jiang, L., P. Sørensen, C. Røntved, L. Vels, and K. L. Ingvartsen. 2008. Gene expression profiling of liver from dairy cows treated intramammary with lipopolysaccharide. BMC Genomics 9:443.

Jørgensen, H. B. H., B. Buitenhuis, C. M. Røntved, L. Jiang, K. L. Ingvartsen, and P. Sørensen. 2012. Transcriptional profiling of the bovine hepatic response to experimentally induced E. coli mastitis. Physiol. Genomics 44:595-606.

Khafipour, E., D. O. Krause, and J. C. Plaizier. 2009. A grain-based subacute ruminal acidosis challenge causes translocation of lipo- polysaccharide and triggers inflammation. J. Dairy Sci. 92:10601070 .

Ko, K., H. Yang, M. Noureddin, A. Iglesia-Ara, M. Xia, C. Wagner, Z. Luka, J. M. Mato, and S. C. Lu. 2008. Changes in S-adenosylmethionine and GSH homeostasis during endotoxemia in mice. Lab. Invest. 88:1121-1129.

Kuprash, D. V., I. A. Udalova, R. L. Turetskaya, N. R. Rice, and S. A. Nedospasov. 1995. Conserved kappa B element located downstream of the tumor necrosis factor alpha gene: Distinct NF-kappa $\mathrm{B}$ binding pattern and enhancer activity in LPS activated murine macrophages. Oncogene 11:97-106.

Lu, S. C. 2013. Glutathione synthesis. Biochim. Biophys. Acta 1830:3143-3153.

Lu, S. C., Z. Z. Huang, H. Yang, J. M. Mato, M. A. Avila, and H. Tsukamoto. 2000. Changes in methionine adenosyltransferase and S-adenosylmethionine homeostasis in alcoholic rat liver. Am. J. Physiol. Gastrointest. Liver Physiol. 279:G178-G185.

Ma, K., Y. Zhang, D. Zhu, and Y. Lou. 2009. Protective effects of asiatic acid against D-galactosamine/lipopolysaccharide-induced hepatotoxicity in hepatocytes and kupffer cells co-cultured system via redox-regulated leukotriene C 4 synthase expression pathway. Eur. J. Pharmacol. 603:98-107.

Mallard, B. A., J. C. Dekkers, M. J. Ireland, K. E. Leslie, S. Sharif, C. L. Vankampen, L. Wagter, and B. N. Wilkie. 1998. Alteration in immune responsiveness during the peripartum period and its ramification on dairy cow and calf health. J. Dairy Sci. 81:585-595.

Martinov, M. V., V. M. Vitvitsky, R. Banerjee, and F. I. Ataullakhanov. 2010. The logic of the hepatic methionine metabolic cycle. Biochim. Biophys. Acta 1804:89-96.

Mato, J. M., F. J. Corrales, S. C. Lu, and M. A. Avila. 2002. S-Adenosylmethionine: A control switch that regulates liver function. FASEB J. 16:15-26.

Mato, J. M., M. L. Martínez-Chantar, and S. C. Lu. 2008. Methionine metabolism and liver disease. Annu. Rev. Nutr. 28:273-293.

Matsuzawa, A., K. Saegusa, T. Noguchi, C. Sadamitsu, H. Nishitoh, S. Nagai, S. Koyasu, K. Matsumoto, K. Takeda, and H. Ichijo. 2005. ROS-dependent activation of the TRAF6-ASK1-p38 pathway is selectively required for TLR4-mediated innate immunity. Nat. Immunol. 6:587-592.

Medzhitov, R. 2008. Origin and physiological roles of inflammation. Nature 454:428-435.

Migita, K., S. Abiru, M. Nakamura, A. Komori, Y. Yoshida, T. Yokoyama, M. Daikoku, T. Ueki, Y. Takii, and K. Yano. 2004. Lipopolysaccharide signaling induces serum amyloid A (SAA) synthesis in human hepatocytes in vitro. FEBS Lett. 569:235-239.

Murata, H., N. Shimada, and M. Yoshioka. 2004. Current research on acute phase proteins in veterinary diagnosis: An overview. Vet. J. 168:28-40.

NRC. 2001. Nutrient Requirements of Dairy Cattle. 7th rev. ed. Natl. Acad. Press, Washington, DC.

Osorio, J. S., P. Ji, J. K. Drackley, D. Luchini, and J. J. Loor. 2014b. Smartamine $\mathrm{M}$ and MetaSmart supplementation during the peripartal period alter hepatic expression of gene networks in 1-carbon metabolism, inflammation, oxidative stress, and the growth hormone-insulin-like growth factor 1 axis pathways. J. Dairy Sci. 97:7451-7464.

Osorio, J. S., E. Trevisi, P. Ji, J. K. Drackley, D. Luchini, G. Bertoni, and J. J. Loor. 2014a. Biomarkers of inflammation, metabolism, and oxidative stress in blood, liver, and milk reveal a better immunometabolic status in peripartal cows supplemented with Smartamine M or MetaSmart. J. Dairy Sci. 97:7437-7450.

Payabvash, S., M. H. Ghahremani, A. Goliaei, A. Mandegary, H. Shafaroodi, M. Amanlou, and A. R. Dehpour. 2006. Nitric oxide modulates glutathione synthesis during endotoxemia. Free Radic. Biol. Med. 41:1817-1828.

Ramadori, G., and B. Christ. 1999. Cytokines and the Hepatic AcutePhase Response. Thieme Medical, Stuttgart, Germany.

Sordillo, L. M., G. A. Contreras, and S. L. Aitken. 2009. Metabolic factors affecting the inflammatory response of periparturient dairy cows. Anim. Health Res. Rev. 10:53-63. 
Sun, S., H. Zhang, B. Xue, Y. Wu, J. Wang, Z. Yin, and L. Luo. 2006. Protective effect of glutathione against lipopolysaccharide-induced inflammation and mortality in rats. Inflamm. Res. 55:504-510.

Uy, B., S. R. McGlashan, and S. B. Shaikh. 2011. Measurement of reactive oxygen species in the culture media using Acridan Lumigen PS-3 assay. J. Biomol. Tech. 22:95-107.

Vels, L., C. M. Røntved, M. Bjerring, and K. L. Ingvartsen. 2009. Cytokine and acute phase protein gene expression in repeated liver biopsies of dairy cows with a lipopolysaccharide-induced mastitis. J. Dairy Sci. 92:922-934.

Yoo, J.-Y., and S. Desiderio. 2003. Innate and acquired immunity intersect in a global view of the acute-phase response. Proc. Natl. Acad. Sci. USA 100:1157-1162.

Yoshioka, M., T. Ito, S. Miyazaki, and Y. Nakajima. 1998. The release of tumor necrosis factor- $\alpha$, interleukin-1, interleukin- 6 and prostaglandin E2 in bovine Kupffer cells stimulated with bacterial lipopolysaccharide. Vet. Immunol. Immunopathol. 66:301-307.

Yuan, K., J. K. Farney, L. K. Mamedova, L. M. Sordillo, and B. J. Bradford. 2013. TNF $\alpha$ altered inflammatory responses, impaired health and productivity, but did not affect glucose or lipid metabolism in early-lactation dairy cows. PLoS One 8:e80316.

Zhang, C., L. M. Walker, J. A. Hinson, and P. R. Mayeux. 2000. Oxidant stress in rat liver after lipopolysaccharide administration: Effect of inducible nitric-oxide synthase inhibition. J. Pharmacol. Exp. Ther. 293:968-972.

Zhang, Q., S. J. Bertics, N. D. Luchini, and H. M. White. 2016. The effect of increasing concentrations of DL-methionine and 2-hydroxy4-(methylthio) butanoic acid on hepatic genes controlling methionine regeneration and gluconeogenesis. J. Dairy Sci. 99:8451-8460. 